\title{
HUBUNGAN KEMAMPUAN SUPERVISI KEPALA RUANGAN DENGAN PELAKSANAAN DOKUMENTASI ASUHAN KEPERAWATAN
}

\section{David Ginting, ${ }^{1}$ Yesika Widiawati Harahap ${ }^{2}$}

Institut Kesehatan Medistra Lubuk Pakam

Jln. Sudirman No. 38 Lubuk Pakam Kab. Deli Serdang e-mail : davidginting@medistra.ac.id

DOI: https://doi.org/10.35451/jkf.v1i2.162

\begin{abstract}
Nursing care documentation is a nursing record that provides information about the client's condition, which can be used as evidence of a nurse's responsibility and accountability in carrying out his duties. Documentation by nurses is very important, so supervision is needed to ensure that the records are in accordance with the standards. This study aims to determine the relationship between the supervising capacity of the head of the room and the implementation of nursing care documentation, with the type of quantitative research being analytic with a cross sectional approach. The population in this study were all nurses who served in the inpatient ward of Grandmed Hospital. Data analysis was carried out by chi square test at $95 \%$ confidence level ( $a=$ 0.05). The results showed that there was a relationship between the supervision capacity of the head of the room and the implementation of nursing care documentation $p$ value $(=0.009)<a(=0.05)$. For the Nursing Field of Grandmed Hospital to carry out supervision in accordance with the standards and carried out regularly 2 times a week.
\end{abstract}

Keywords: Documentation, Supervision

\section{PENDAhUlUAN}

Dokumentasi asuhan keperawatan adalah keadaan pasien yang ditulis secara keseluruhan mengenai seluruh keadaannya selama berada dalam rawatan di pelayanan kesehatan. Catatan ini dapat digunakan sebagai bukti bagi individu jika ada satu keadaan yang harus dibuktikan secara hukum (Anggeria, 2015). Dokumentasi ini berperan sebagai bukti otentik tertulis terhadap peradilan atau hukum yang berlaku, sehingga dibutuhkan pendokumentasian asuhan keperawatan yang baik.
Dokumentasi ini juga berfungsi sebagai alat komunikasi dan kerjasama antar berbagai profesi. Kerjasama ini dapat berupa pengumpulan data dan mengkaji dan menganalisis status pasien, dan menyusun rencana serta mengevaluasi asuhan keperawatan yang diberikan kepada pasien. Melalui doumentasi ini didapatkan berbagai manfaat dalam upaya pemberian pelayanan terbaik kepada pasien/klien (Hidayat, 2012). Kualitas dokumentasi dilihat dari bagaimana kepatuhan perawat terhadap aturan pendokumentasian yang ditetapkan oleh profesi atau pemerintah, misalnya 
kelengkapan dan keakuratan menuliskan asuhan keperawatan dimana dokumentasi yang dikerjakan sesuai standar yang telah ditetapkan mulai dari menuliskan tanggal, waktu dan sesuai dengan kondisi pasien selama mendapatkan rawatan di pelayanan kesehatan (Nursalam, 2014).

Untuk mendapatkan hasil yang baik, seorang perawat sangat membutuhkan pengawasan, pengarahan dan pendampingan melalui kegiatan supervisi. Supervisi merupakan kegiatan penting yang dapat memberi pengaruh terhadap peningkatan mutu pelayanan keperawatan, bahkan pelayanan kesehatan di rumah sakit akan berdampak terhadap baik tidaknya pendokumentasian yang dilakukan (Helendina dkk, 2015).

$$
\text { Studi pendahuluan yang }
$$

dilakukan di RS Grandmed, dari didapatkan bahwa 7 orang perawat mengatakan mengalami kesusahan dalam penulisan dokumentasi hal tersebut dapat dilihat dari dokumentasi keperawatan bahwa pengkajian tidak dikelompokkan dan hanya menuliskan data biologis sedangkan data psikologis, sosial dan spritual tidak terkaji secara jelas, diagnosa keperawatan sudah muncul tapi diagnosa yang tercantum hanya satu diagnosa yang ditegakkan dari klien datang hingga pulang dan tidak merumuskan diagnosa aktual atau potensial. Perencanaan keperawatan, tidak terdapat rumusan tujuan yang memuat komponen klien, perubahan, perilaku, kondisi klien atau kriteria hasil. Sedangkan evaluasi didokumentasikan dengan mengacu pada standar Subjektif, Objektif, pengkajian dan Rencana (SOAP).

Hasil wawancara peneliti dengan beberapa supervisor, didapatkan bahwa supervisor belum bisa menjalankan tugasnya sebagai secara maksimal karena selain menjadi supervisor mereka juga merangkap sebagai kepala ruangan dan mereka harus menjadi supervisor di ruangan yang berbeda.

Berdasarkan uraian di tersebut maka peneliti tertarik untuk melakukan penelitian mengenai hubungan kemampuan supervisi kepala ruangan dengan pelaksanaan dokumentasi asuhan keperawatan.

\section{METODE PENELITIAN}

Jenis penelitian merupakan penelitian kuantitatif bersifat analitik dengan menggunakan pendekatan cross sectional yang bertujuan untuk menganalisis hubungan supervisi kepala ruangan dengan pelaksanaan dokumentasi asuhan keperawatan. Populasi dalam penelitian ini adalah seluruh perawat pelaksana yang bertugas di ruang rawat inap lantai 5 RS Grandmed sebanyak 25 orang yang seluruhnya dijadikan sampel dalam penelitian ini.

Instrumen yang digunakan adalah kuesioner dengan variabel supervisi menggunakan 20 pertanyaan. Variabel supervisi dikategorikan berdasarkan baik dan kurang baik sedangkan asuhan keperawatan jumlah pernyataan sebanyak 16 pernyataan dengan kategori baik dan kurang baik.

\section{HASIL}

\section{a. Supervisi kepala ruangan}

Berdasarkan gambaran supervisi kepala ruangan dapat dilihat bahwa mayoritas supervisi kepala ruangan dalam kategori kurang yaitu 13 orang (52\%) sedangkan kategori baik 12 orang $(48 \%)$. 
Tabel 1. Distribusi frekuensi supervisi kepala ruangan $(n=25)$

\begin{tabular}{clcc}
\hline No & Supervisi & f & \%) \\
\hline 1 & Baik & 12 & 48,0 \\
2 & Kurang baik & 13 & 52,0 \\
\hline
\end{tabular}

\section{b. Asuhan keperawatan}

Berdasarkan

gambaran

pelaksanaan asuhan keperawatan dapat dilihat bahwa mayoritas pelaksanaan asuhan keperawatan berada dalam kategori baik yaitu 13 orang $(52 \%)$ sedangkan kategori kurang baik 12 orang (48\%).

Tabel 2. Distribusi frekuensi pelaksanaan asuhan keperawatan $(n=25)$

\begin{tabular}{clcc}
\hline No & Pelaksanaan & f & \%) \\
\hline 1 & Baik & 13 & 52,0 \\
2 & Kurang baik & 12 & 48,0 \\
\hline
\end{tabular}

c. Hubungan supervisi kepala ruangan dengan pelaksanaan asuhan keperawatan

Berdasarkan hasil penelitian menunjukkan, kemampuan supervisi kepala ruangan baik dengan pelaksanaan dokumentasi asuhan keperawatan baik sebanyak 10 orang $(83,3 \%)$. Kemampuan supervisi kepala ruangan kurang baik dengan pelaksanaan dokumentasi asuhan keperawatan kurang baik sebanyak 10 orang $(76,9 \%)$. Berdasarkan hasil uji statistik dengan menggunakan uji Chi Squere menunjukan bahwa pValue $(=0.009)<a(=0,05)$. Maka dapat disimpulkan bahwa Ha diterima yaitu ada hubungan kemampuan supervisi kepala ruangan dengan pelaksanaan dokumentasi asuhan keperawatan.
Tabel 3. Hubungan supervisi kepala ruangan dengan pelaksanaan dokumentasi asuhan keperawatan

\begin{tabular}{|c|c|c|c|c|c|c|c|}
\hline \multirow{3}{*}{$\begin{array}{l}\text { Su } \\
\text { pe } \\
\text { rvi } \\
\text { si }\end{array}$} & \multicolumn{4}{|c|}{$\begin{array}{c}\text { Asuhan } \\
\text { Keperawatan }\end{array}$} & \multirow{2}{*}{\multicolumn{2}{|c|}{ Total }} & \multirow[t]{3}{*}{$\begin{array}{l}\text { pVa } \\
\text { lue }\end{array}$} \\
\hline & \multicolumn{2}{|c|}{ Baik } & \multicolumn{2}{|c|}{$\begin{array}{c}\text { Kurang } \\
\text { Puas }\end{array}$} & & & \\
\hline & $F$ & $\%$ & $f$ & $\%$ & $f$ & $\%$ & \\
\hline $\begin{array}{c}\text { Bai } \\
\text { k }\end{array}$ & $\begin{array}{l}1 \\
0\end{array}$ & $\begin{array}{r}83 \\
, 3\end{array}$ & 2 & $\begin{array}{c}16 \\
7\end{array}$ & $\begin{array}{l}1 \\
2\end{array}$ & $\begin{array}{l}1 \\
0 \\
0\end{array}$ & \\
\hline $\begin{array}{l}\text { Ku } \\
\text { ra } \\
\text { ng } \\
\text { bai } \\
\text { k }\end{array}$ & 3 & $\begin{array}{l}23 \\
1\end{array}$ & $\begin{array}{l}1 \\
0\end{array}$ & $\begin{array}{c}76, \\
9\end{array}$ & $\begin{array}{l}1 \\
3\end{array}$ & $\begin{array}{l}1 \\
0 \\
0\end{array}$ & $\begin{array}{l}0,0 \\
09\end{array}$ \\
\hline
\end{tabular}

\section{PEMBAHASAN}

\section{a. Supervisi kepala ruangan}

Supervisi merupakan upaya yang dilakukan oleh seseorang yang diangkat dalam suatu organisasi untuk melakukan pembinaan, bimbingan, atau pengawasan oleh pengelola program terhadap pelaksana di tingkat administrasi yang lebih rendah dalam rangka menetapkan kegiatan sesuai dengan maksud dan sasaran yang telah ditetapkan (Muninjaya, 2012).

Hasil penelitian menunjukkan bahwa supervisi kepala ruangan kategori baik 12 orang $(48 \%)$ dan kurang baik sebanyak 13 orang (52\%). Hasil penelitian ini sesuai dengan pendapat Agung (2015) bahwa supervisi menjadi pemicu bagi setiap anggota yang berkerja sehingga memberikan kontribusi yang positif untuk kemajuan organisasi. Kemampuan yang dimiliki supervisor dalam memilih dan menentukan pekerjaan setiap pegawai membuat pekerjaan semakin efektif sehingga peningkatan kemampuan supervisor menjadi sangat ditentukan bagaimana dia mampu memberikan pengawasan, pembinaan, dan bimbingan. 
Supervisi dilaksanakan oleh Kepala Ruangan untuk melihat kepatuhan perawat pelaksana, dalam mengidentifikasi masalah dan membantu pemecahan masalah dalam melaksanakan asuhan keperawatan (Muninjaya, 2012).

Menurut asumsi peneliti bahwa kegiatan supervisi sangat jarang dilakukan oleh Kepala Ruangan. Tidak adanya jadwal tetap kegiatan supervisi menyebabkan para perawat menjadi kurang termotivasi untuk melaksanakan asuhan keperawatan dengan baik. Kegiatan supervisi hanya dilakukan apabila akan ada kunjungan dari pusat atau ada kejadian yang membuat dilakukannya pengawasan terhadap kinerja perawat. Kegiatan supervisi yang terarah dan berkelanjutan merupakan sistem pembinaan yang efektif bagi pelembagaan

\section{b. Pelaksanaan Dokumentasi Asuhan Keperawatan}

Hasil analisis menunjukkan bahwa bahwa dokumentasi asuhan keperawatan yang dilaksanakan oleh perawat berada dalam kategori baik yaitu 13 orang $(52,0 \%)$ dan dokumentasi asuhan keperawatan kategori kurang baik sebanyak 12 orang (48,0\%). Kelengkapan pendokumentasian asuhan keperawatan juga disebabkan oleh tingginya beban kerja perawat setiap shift. Hasil penelitian beban kerja dilihat berdasarkan shift menemukan bahwa shift pagi dan shift sore ratarata perawat mempunyai beban kerja tinggi. Hal ini diperkuat oleh hasil penelitian Wiyana (2014) yang menyatakan bahwa adanya keterkaitan antara shift pagi dengan kualitas pendokumentasian dibanding shift sore dan malam. Hasil penelitian juga memperlihatkan lama waktu dinas perawat berlebih dari full time ekuivalen (FTE) perawat untuk shift pagi, shift sore, dan shift malam. Hal lain yang mengindikasikan beban kerja perawat tinggi adalah peneliti menemukan 6 orang perawat terpaksa harus double shift, hal itu dilakukan karena banyaknya kegiatan perawat terutama shift pagi dan sore sehingga memengaruhi pelaksanaan pendokumentasian asuhan keperawatan.

Pendokumentasian menjadi kurang efektif disebabkan oleh beban kerja perawat yang bertambah yang disebabkan oleh banyaknya pekerjaan dan berulang karena disebabkan oleh perawat itu sendiri (Dinarti, 2015). Sedangkan Agung (2015) menyatakan bahwa perawat dalam melakukan pekerjaannya kerap menyebabkan demotivasi yang disebabkan oleh beberapa hal seperti jam kerja yang panjang, dampak jam kerja malam, kekurangan tenaga keperawatan karena beban kerja tinggi, gaji rendah, dan kurang penghargaan.

\section{Hubungan supervisi kepala ruangan dengan pelaksanaan dokumentasi asuhan keperawatan}

Hasil analisis menunjukkan bahwa dari 25 orang, kemampuan supervisi kepala ruangan baik dengan pelaksanaan dokumentasi asuhan keperawatan baik sebanyak 10 orang $(40,0 \%)$. Kemampuan supervisi kepala ruangan baik dengan pelaksanaan dokumentasi asuhan keperawatan baik sebanyak 10 orang $(40,0 \%)$. Berdasarkan hasil uji statistik dengan menggunakan uji Chi Squere menunjukan bahwa pValue $(=0.041)<$ a $(=0,05)$. Maka dapat disimpulkan bahwa Ha diterima yaitu ada hubungan kemampuan supervisi kepala ruangan dengan pelaksanaan dokumentasi asuhan keperawatan di Ruangan Rawat Inap Rumah Sakit Grandmed Lubuk Pakam Tahun 2019. 
Hal ini menunjukan bahwa tingkat kemampuan yang dimiliki kepala ruang di instalasi rawat inap rumah sakit Grandmed Lubuk Pakam cukup baik. Saat ini di rumah sakit Grandmed Lubuk Pakam sudah mulai dilakukan supervisi secara berkesinambungan sehingga kepala ruang mulai membekali diri dengan kemampuan yang cukup sebelum melakukan supervisi terhadap perawat pelaksana. Begitu juga dengan dilaksanakan audit terhadap dokumentasi keperawatan kepala ruang juga dituntut untuk mampu mendorong perawat pelaksana melakukan pendokumentasian secara lengkap dan akurat.

Kepala ruangan bertanggung jawab terhadap pelaksanaan supervisi pelayanan keperawatan yang diberikan pada pasien di ruang perawatan yang dipimpinnya. Sedangkan kepala ruangan mengawasi perawat pelaksana dalam memberikan asuhan keperawatan baik secara langsung maupun tidak langsung (Suyanto, 2008). Untuk itu kepala ruang sebagai supervisor harus dapat menguasai beberapa kompetensi untuk melaksanakan supervisi keperawatan. Kompetensi merupakan kualitas pribadi/kemampuan untuk melaksanakan tugas yang diperlukan.

Menurut pendapat peneliti belum optimalnya kinerja perawat terlihat pada hasil kerja perawat pelaksana yang tergambar pada pendokumentasian yang belum sesuai standar yang ditetapkan. Banyaknya pendokumentasian yang tidak lengkap juga merupakan salah satu faktor. Pada aspek pengkajian banyak perawat melakukan pengkajian dengan tidak lengkap dan perumusan diagnosa bukan berdasarkan dari hasil pengkajian yang telah dikelompokkan dalam format pengkajian. Pada aspek perencanaan dan tindakan keperawatan perawat cenderung berdasarkan rutinitas dan tidak mengacu pada masalah keperawatan yang dibuat, revisi tindakan berdasarkan evaluasi respon juga jarang dilakukan.

\section{KESIMPULAN}

Berdasarkan hasil penelitian bahwa distribusi frekuensi untuk kemampuan supervisi kepala ruangan berada dalam kategori kurang baik sebesar $52 \%$ sedangkan pelaksanaan dokumentasi asuhan keperawatan dalam kategori baik sebesar $53 \%$.

Berdasarkan hasil uji statistic dengan menggunakan uji chi-square menunjukkan bahwa $p$ value $=0.009$ $<\mathrm{a}=0.005$ ada hubungan supervisi kepala ruangan dengan pelaksanaan dokumentasi asuhan keperawatan di ruang rawat inap RS Grandmed tahun 2019.

\section{DAFTAR PUSTAKA}

Anggeria. (2015). Pelayanan Kesehatan. Graha Ilmu, Yogyakarta.

Dinarti, (2015). Analisis Faktor - Faktor Pelaksanaan Dokumentasi Asuhan Keperawatan di Rumah Sakit Umum Daerah Tugurejo Semarang. Tesis. Program Pasca Sarjana Universitas Diponegoro Semarang

Helendina Senorita, Sitanggang Linda \& Rustika. (2015). Hubungan Supervisi Kepala Ruangan dengan Perilaku Perawat dalam Pendokumentasian Asuhan Keperawatan di Ruang Rawat Inap Rumah Sakit Premier Jatinegara Jakarta Timur. Artikel IImiah STIK Sint Carolus

Hidayat, (2012). Pengantar Konsep Dasar Keperawatan. Jakarta : Salemba Medika

Muninjaya. (2012). Manajemen Kesehatan. Edisi 3. Jakarta. EGC. 
Nursalam (2014). Manajemen Keperawatan. Salemba, Jakarta

Pribadi, Agung. (2015). Analisis Pengauh Faktor Pengetahuan, Motivasi dan Persepsi Perawat tentang Supervisi Kepala Ruang terhadap Pelaksanaan Dokumentasi Asuhan Keperawatan di Ruang Rawat Inap RSUD Kelet Provinsi Jawa Tengah di Jepara. Universitas Diponegoro : Semarang

Setiadi. (2012). Manajamen Keperawatan dengan Pendekatan Praktis. Jakarta: Erlangga.

Simamora, H. (2014). Manajemen Sumber daya Manusia, Edisi III, STIE YPKN, Yogyakarta.

Wiyana, S. (2014). "Analisis Kompetensi Kepala Ruang dalam Pelaksanaan Standar Manajemen Pelayanan Keperawatan dan Pengaruhnya Terhadap Kinerja Perawat dalam Mengimplementasikan Model Praktik Keperawatan Profesional di Instalasi Rawat Inap BRSUD Banjarnegara". 